p-ISSN: 2308-4944 (print) e-ISSN: 2409-0085 (online)

Volume: 35

Published: $30.03 .2016 \quad$ http://T-Science.org

SECTION 30. Philosophy.

\title{
IS ARAL SEA OR LAKE? (SOME THOUGHTS ABOUT THE REASONS THAT TURNED THE ARAL SEA INTO THE LAKE, MORE PRECISELY INTO THE DESERT “ARALKUM”)
}

Abstract: In the article there is analyzed complex-systematically the main objective reasons of drying of Aral Sea subjective factors. There is defined the sharpening of ecologic state in the region and its globalization tendency. There is given opinion about potential opportunities of creating healthy stable ecologic environment and strategic tasks.

Key words: utilitar - mercantile benefits, potential opportunities, strategic tasks, local water basins, tendency of globalization, real ecologic essence, national egoism, Complex program of improving the ecologic state in the region of Aral Sea, institutional system, Global ecologic fund, ecologic inspection, hydro technical constructions, realization in a differentiating way, eco complex of biosphere.

Language: English

Citation: Omonov B (2016) IS ARAL SEA OR LAKE? (SOME THOUGHTS ABOUT THE REASONS THAT TURNED THE ARAL SEA INTO THE LAKE, MORE PRECISELY INTO THE DESERT “ARALKUM”). ISJ Theoretical \& Applied Science, 03 (35): 63-67.

Soi: http://s-o-i.org/1.1/TAS-03-35-11 Doi: crossef http://dx.doi.org/10.15863/TAS.2016.03.35.11

In the 60ths of XX century the Aral Sea took the $4^{\text {th }}$ place by its size after such "closed seas" of the world as Caspian, Lake Superior in Northern America and Victoria in Africa. That has to say, its area of 67000 square $\mathrm{km}$ was equal to the area of such European countries as Albania, Belgium and Cyprus. This sea have been very important in keeping the balanse of ecocomplex for 35000 years (for 20000 years according to some information, that's to say even if its younger by the age from Caspian sea to 1000 times[1; -P.129-144].

Nowadays, as it was underlined by the Prezident of the Republic of Uzbekistan, "increasing of the number of population and their need in water, the rapid land development, regular appear of the years with scarcity of water caused the occurrence of one of the most huge global ecologic problems - the drying of one of the most beautiful water ponds.... Nowadays in front of the whole humanity the sea is dying... we can sea that the desert that appeared here is spreading around the territory of the Aral without remorse. Nowadays it is absolutely clear that there occurred a complex of difficult ecologic, socialeconomical and demographic problems in the region of Aral sea".[2;-P.209-211]. In order to define the genesis of occurring of these problems, it's necessary to analyze the system of their problems. As, absoluting the role of a separate factors in worsening of ecological state in a separate territory or in a global scale causes rough conclusions.

In the literatures, that have been existing till nowadays, as the main reasons for Aral Sea's drying prevail such reasons as the groundlessness of the strategy of placing the producing power, mechanical content of land, not taking into consideration the hydrogeological and geomorphological condition, projecting the system of irrigation and hydro technical construction, lowness of the affectivity of construction and using them, not differenced of the irrigation norms and standards, in short connecting it with carrying out economy extensively by the oppressive system.

Of course, they are the main reasons, but the main reason is that in the USSR the welfare of country stood higher that the welfare of society and person. In the former USSR in the $80^{\text {th }}$ of past century, the scale of social, economical, ecologic problems connected with drying of the Aral Sea became definite and as in every other spheres the state started to work out its plans of eliminating it, that were of urgent and declarative character. Especially, in 1986-1990 in order to develop socially 
and economically the autonomous republic of Karakalpakistan it was assigned money in the amount of 3,5 billion sum (taking into consideration that 0,7 sumwas equal to 1 USD that times, the amount of this money can be seen clearly). But the time was passed. If money in that quantity were separated when the Aral sea started drying and were used purposefully, today, maybe drying of the Aral sea and social - ecological problems connected with it wouldn't be put into agenda.

Uzbekistan's position in the world community integration into it is also tightly connected with finding of its own place in global ecologic relations. It was quite obvious even in primary years that decreasing of Aral sea's level can cause disastrous consequences. The researches of hydrogeologist A.Esenbekov carried out in 1968 in lower Amuderya defined that from the drying territory of Aral sea annually drops from $617 \mathrm{~kg}$ up to $688 \mathrm{~kg}$ salt into each hectare of land by the wind [3;-P.161]. But even if the correspondent member of the Academy of Sciences of the former USSR V.N.Kuninin 1967 in his article printed in the magazine "Природа" (Nature)assessed drawing the potable water for thousands kilometers through the deserts and steppes, when it was possible to receive much more harvest per each square metres as thriftlessness, his colleague doctor of geographic sciences Yu.S.Geller made such optimistic conclusion as "even if the Aral sea dries and irrigating square around it becomes 4 million hectares, the amount of agricultural products, obtained every year from these lands will be preserved higher for 100 times than the incomes of fishing economies in the Aral Sea [1;-P.161]. The most pitiful thing is that in that times both the local governors of countries of the region and scientists supported this point of view. The cotton policy of the USSR was put higher than objective facts, social and ecologic need. This police was based on irrationalism, volunteerism beginning from 20s years. In the first five-year-plans in 1932 it was marked to separate 67 percent of irrigating lands for cotton planting. That is why, when the matter was about cotton, the social, economical and cultural need of Aral sea was not taken into consideration.Variegation of nature, the balans of biosphere - ecological need was not acknowledged as value at all. It is pity that such point of views, had been preserved as a stereotype in USSR for manyyears.For exapmle, in the 70 th years of the past century the desert institute director of Turkmenistan Academy of Science, professor Babaev A. in his interviews given to the media stated repeatedly: "I am in a row of scientist that considers that the Aral sea's drying will bring more use than preserving it. Because, firstly, from the undeveloped fertile lands in this zone every year, only cultivated 1,5 million ton of cotton is higher than the economical indicators of all economies and covers all the damage. Secondly, drying of the land won't damage the landscape of the region" [1; -P.162], Pitiful state of such "optimistic" conclusions put the life of more than 50 million people under a big danger. In the result in the region of Aral sea there aroused the ecological crisis connected with its drying, and the scale of this problem became especially dangerous in the 60s of XX century. In Uzbekistan the area of cotton fields widened from 441600 hectares in 1913 to 1 million hectares in 1940, from 1,4 hectares in 1960 to 2,1 million hectares in $1987[3 ;-P .214]$. In the result the ecological damage was much more higher than income that came from agriculture and created unfixable dangerous ecologic territory. Number of plants had decreased dramatically, and the lands used in livestock covered with thick salt.Such dangerous illnesses for human's life as anaemia, cancer, liver cirrhosis, goiter, increasing of blood pressure and other diseases like that increased among the people.

The Aral sea was the forth water basin among inner seas of the world. Nowadays it felt may be into nineteenth or twentieth places. The sea moved 120$200 \mathrm{~km}$ away from the coast and left a salty desert of more than 45 thousand square $\mathrm{km}$ in the depth of sea. From the drained bottom of the Aral, where there is always wind and appears storm cyclones, rise 75 million tones of sand and 65 million of thin dispersion dust every year, and this becoming the reason for decreasing of productivity in valleys and cultural plants. In the territory of Aral sea moving of dust and salt appears in the radius of $300 \mathrm{~km}$ and in the territory of Sothern Aral the amount of dust dropping into the sand is more for 10 times rather than irrigated lands.Because of collapse of sea the number of 174 kind of animals decreased up to 38 [3; -P.213].

The area of Aral sea basin is 1.5 million square kilometers, its population is more than 50 million people. There are six countries (Uzbekistan, Turkmenistan, Tajikistan, Kyrgyzstan, Kazakhstan and Afghanistan) are situated around the region. The surface of water area of Aral sea in 1960 was 67000 $\mathrm{km} 2$ (the 4th lake by size); height of water level (concerning the level of Baltic sea)was $53 \mathrm{~m}$, volume was $1040 \mathrm{~km} 3$, amount of salt in water was $10 \mathrm{~g} / \mathrm{l}$. Nowadays the Aral sea has dived into two Big and Little Aral. According to the indicators of 2012 the surface of water area of Big Aral is $15250 \mathrm{~km} 2$, the height of water level(concerning the water bottom of Baltic sea): is $30,7 \mathrm{~m}$, volume is $89.4 \mathrm{~km} 3$, the amount of salt in the water $72 \mathrm{~g} / \mathrm{l}$, and the surface of Little Aral's water area is $2860 \mathrm{~km} 2$, height of water level сув сатхининг баландлиги (concerning the water bottom of Baltic sea)is $41,0 \mathrm{~m}$, volume is 22.5 $\mathrm{km} 3$, amount of salt in water is $72 \mathrm{~g} / \mathrm{l}$.

It was equal to the amount of water that felt into the Aral and evaporated from it, and filtrated up 
to1960. Every year 57-60 km3 water dropped into the Aral and the same amount water was lost. The former USSR in 1960 planned to broaden the irrigation sphere of agriculture and turn it into the country that produces cotton most of all. In the Middle Asea the territory of irrigated areas was increased from $5 \mathrm{mln}$ Hectares (1960y.) to $8 \mathrm{mln}$ hectares (1980y). In order to water these lands taking water from rivers were increased from $40 \mathrm{~km} 3$ to $132 \mathrm{~km} 3$.

The main part of water was used for irrigational purposes.

Developing new lands fastly, making irrigating agriculture more developed, constructing irrigational systems along the territory of whole Central Asia for this, the constant increase of need in using water in economical and industrial scale, and also regularly repeating years with water deficitcaused the occurrence of one of the most global ecologic disasters - drying of a water basin that sometimes was one of the most beautiful ones in our planet. In the last 50 years the level of water area of Aral Sea decreased for more than 7 times, volume of water lessened for 13 times, its mineralization increased exactly at this number. [5; -P.15]

The USSR's policy of carrying economy, based on colonization expressed false humanity and was subordinated to the abstract benefits of "soviet people". When to look superficially, widening productivity in national countries, as if even corresponded to the benefit's of the country, in real in essence it consisted of exploitation its nature, human resources pursuing the benefits of center. National values were plundered. "The idea of treating the wealth of the country carefully was absolutely alien to the whole essence of socialist system of carrying economy that was based on using the reserves of natural and mineral raw materials cruelly, in extensive method, with very big expenses and waste" [4;-P.110]. Exactly this attitude must be assessed as anti-humanious consequence of soviet policy. Especially, using the water resources of the Aral sea situated in our region temporarily on the basis of utilitary-mercantile benefits from the point of getting net economical income became one of the main reasons for its drying.

The plan of preserving the sea by the former Union, the officials and specialists began to offer unbelievable projects in order to improve the state after there were occurred negative results because of decreasing of volume, level and water area of the sea. First of them, was to change the mountain chain Pamir by explosion (It causes a very big danger for human life and ecologic system in region).

The second, was to turn the rivers $\mathrm{Ob}$ and Yenisei to the Central Asia, and to construct Main channel of $2500 \mathrm{~km}$ length. That was the biggest project in the history of former Union, and the project was approved in the beginning of 80 years for implementation and stopped in 1987 (the economic and ecologic consequences of this project were not studied completely, and this variant demanded very big money and, mainly political agreement between the countries). Besides, the public, especially the intelligentsia started to come out against it.

The third, the project of drawing a $500 \mathrm{~km}$ length channel from the Caspian sea (the level of the Caspian sea is situated $71 \mathrm{~m}$ lower than the level of Aral sea.Raising the water to such level and making it reach the Aral sea requires very big amount of money and energy resource, and implementing this project is also considered as impossible ones). All of these projects ended without any success.

Two great rivers of the Central Asia -Amudarya and Sir-darya saturate the Aral sea. The annual water resources of Amu-Darya basin is more than 78 $\mathrm{km}^{3}$ and $62,9 \mathrm{~km}^{3}$ of it (more than $80 \%$ ) formed in Tajikistan, $4,7 \mathrm{~km}^{3}$ comes to the share of Uzbekistan. The annual water resources of Sir-Darya makes about $38,8 \mathrm{~km}^{3}$. Here in Kyrgyzstan $28 \mathrm{~km}^{3}$ $(72,2 \%)$, in Uzbekistan - 5,59 $\mathrm{km}^{3}(14,4 \%)$, in Kazakhstan $-4,08 \mathrm{~km}^{3}(10,5 \%)$ and in Tajikistan 1,1 $\mathrm{km}^{3}(0,3 \%)$ of water resources are formed. It is defined that in the national economy of Uzbekistan the existing volume of water applicable for usage is $67 \mathrm{~km}^{3}$, from rivers $-55,1 \mathrm{~km}^{3}$, from underground waters $-7,8 \mathrm{~km}^{3}$, from circular waters $-4,1 \mathrm{~km}^{3}[3$; P.152].

Carrying out of its ecologic policy by the world countries alternatively provides being complex of global ecologic policy. Because in the global ecologic space peculiarity of every country came out of a definite circumstance, concrete "ecologic mission" forms the composition of generality and is mutually connected with dialectic way. It is reflected not only in the place of international ecologic political relations of the national, regional countries, but also in organizational forms of political institutions of a global level. Mutual relations of national and regional countries' ecologic organizations are acknowledged in special legal documents of geopolitical space of the world. Forming of the unified, made similarlegal-lawful space of the global ecologic policy is considered as a result of transformation and integration of general ecologic values on a national and regional scale. In the region of the Aral Sea formation of integrative ecologic policy of the country of Uzbekistan and the government of Kara-kalpak, its reforms and modernization must come out from the concrete social - ecologic state. For example, according to the information of Nature preservation Commetee of the Republic of Uzbekistan, there isn't any zones with convenient ecologic conditions in the Republic of Kara-Kalpak.In the zone with very grave (sharp) ecologic condition there is only in two administrative 
district (Buzatov and Shumanay districts - about 308, 3 thousand hectares, population - 59,2 thousand) out of 22 situated, only $4 \%$ of population of the republic live here, Muynak district - area- 3675, 8 thousand hectares. It is announced as a disaster zone where there live 27,8 thousand people. The rest area of the Republic of 12116,3 thousand hectares, or its territory with 1331, 1 thousand people is acknowledged as a zone with extraordinary ecologic circumstance [6; -P.176]. Such a state reflects peculiar rules arisen in the region of Aral sea.The compound structure of ecological policy of the countries of Central Asia (there is provided the institutional structure), its modernization and reconstruction requires the model of international cooperation, realization differentially in a definite ecologic space. And this, in its turn, is a term of providing the development of stable ecologic and firmness of ecologic balance in the regions. That is why, in the territories with a sharp ecologic condition, autonomy of the model of national and regional ecologic policy and its independence has relative and conditional character.

Now, the general conclusion of scientists, specialists is that ecologic problems are of a global character without any exception. Even when the offers regarding salvation of ecologic problems don't contradict to the benefits of people of different countries that are situated in the region, there arouse alternative views, directions of practical activity on this matter. Mostly, some politics, that lost their heads because of the independence and was put under the effect of "national egoism" syndrome are pushing forward disputable ineffective opinions on ecologic problems of the region. Particularly, the matters of dividing and using the water resources in the region wisely, even starting to be put into center of attention of the world community. It can be seen also on pages of one of the mass electronic publication of France - "Les milieux des empires" c

in the article named "The viewpoint regarding using the water resources by the Republic of Uzbekistan". On that article there was stated that drying of the Aral Sea can cause huge consequences not only for the countries of Aral Sea, but also for the huge subregion, even for the all countries of Eurasia, "Every country has right to use the water reserves of transboundary rivers, including implementing the projects connected with constructing hydro technical construction. But in that case they must be passed a firm independent technical-economical and ecological inspection based on openness and on interested sides' being informed fully, on this point there must be guaranteed the following two very important terms:

firstly - the amount of money must not be decreased for the countries situated in the lower part of current;

secondly - the ecologic state which is difficult even without this, must not be distroyed", [7] came to general conclusion like this.

From the mentioned above we can make the following generalizing conclusion:

1. Reconstruction of Amu-darya delta. Not to throw the water coming from Amu-darya delta to the sea, to form local water basins from its delta, to develop fishing and cattle-breeding thereand provide the population with work (sending water into the sea will not give any effect because it will evaporate).

2. In order to decrease the dust mixed with salt which spreads from the dried bottom of the Aral by the wind it is necessary to increase the types of plants enduring to saline. With the help of Global Ecologic fund of the Republic of Uzbekistan and also in the account of its own money carrying a lot of projects (on this matter in Uzbekistan there were planted saxauls in the dried bottom of sea of about 200 thousand hectares and these works are continuing to be carried out).

3. The complex program of ecological policy of Uzbekistan that are being carried out in the Aral sea regionrequires being adequate to the occurred real ecologic essence.

4 The process of integration and globalization of international ecologic political relations corresponds to the universal benefits, and the Complex program of Countries of Central Asia of improving the ecologic state in the region of Aral sea is concretizing the strategic tasks.

5. The tendency of sharpening and globalization of ecologic statein the region connected with drying of Aral sea, is strengthening the attention of world community and causes formation institutional system of international political cooperation and monitoring.

\section{References:}

1. Oreshkin D (1990) "Times connecting the thread. The Aral: today and tomorrow" (Vremen svyazuyushchaya nit'. Aral: segodnya i zavtra.) /Somp. K.Sh.Diyarova, G.V.Geldeyeva. - Alma-Ata: Kaynar, 1990. pp. 129-144. (280 - P) 
\begin{tabular}{l|lrl|l|ll} 
& ISRA (India) & $=\mathbf{1 . 3 4 4}$ & SIS (USA) & $=\mathbf{0 . 9 1 2}$ & ICV (Poland) & $=\mathbf{6 . 6 3 0}$ \\
Impact Factor: & ISI (Dubai, UAE) $=\mathbf{0 . 8 2 9}$ & PUHL (Russia) $=\mathbf{0 . 1 7 9}$ & PIF (India) & $=\mathbf{1 . 9 4 0}$ \\
& GIF (Australia) & $\mathbf{0 . 5 6 4}$ & ESJI (KZ) & $=\mathbf{1 . 0 4 2}$ & IBI (India) & $=\mathbf{4 . 2 6 0}$ \\
& JIF & $\mathbf{1 . 5 0 0}$ & SJIF (Morocco) & $=\mathbf{2 . 0 3 1}$ & & \\
\hline
\end{tabular}

2. Karimov IA (2009) Ensure a consistent and sustainable development of our country's most important task tom17 "Uzbekistan" 2009. -280 p.

3. Kovolev V (1988) And sea, And cotton...Fate of Aral (I more, i khlopok... // Sud'ba Arala.) Tashkent, "Mehnat(Labor)" 1988. -pp.183.

4. Mamashokirov S (2012) "Whether it's panic or reality” (Vaximami eki хақіқаt.) Tashkent, "Economy -finance(Iқtisod-moliya)" 2012. pp.230.

5. Karimov IA (1998) In the way of security and stable development. Volume 6 . $-\mathrm{T}$.: Uzbekistan, 1998. -429 p.
6. (2008) National lecture about environmental state and using natural resources in the Republic of Uzbekistan -2008. Tashkent. Page 176.

7. (2009) "Les milieux des empires" states that it's necessary to use water resources in the Central Asia wisely. //Halk suzi (Voice of people). February 10, 2009.

8. (2013) Constitution of the Republic of Uzbekistan. T.: 2013. -40 p.

9. Karimov IA (2008) Yuksak ma`naviyat yengilmas kuch. T.: 2008.

10. Karimov IA (2015) Serving native homeland in the way of a happy and a great future - the highest happiness. T.: Uzbekistan, 2015. 